\title{
The Impact of Physical Activity to Physical Fitness and Nutrional Status of Grade X Surabaya Vocational High School
}

\author{
Galih Prasetyo $^{1}$, Suroto ${ }^{2}$, Dwi Cahyo Kartiko ${ }^{3}$ \\ 1,2,3Sport Education Universitas Negeri Surabaya, Indonesia \\ Email: galihprasetyo271@gmail.com
}

\begin{abstract}
The purpose of this research is to improve physical fitness which is one of the goals of physical education in Indonesia while also improving the nutritional status of Surabaya vocational high school students. This research uses the treatment of physical activity 3 times a week in 2 months as a task in physical education to improve physical fitness and nutrional status on the sample of this research. Research design uses quasi experimental design with metode non-randomized control group pretest-posttest design. Research data was obtained as follows: data processing result on experiment group show that physical activity to VO2max got significant score based calculating using SPSS of 0,00 and physical activity to nutrional status got sig. of 0,60. Whereas in the control group, physical actifity got sig. of 0.20 to VO2max and sig. to 0.11 on nutrional status. Based on the above analysis it can be concluded that physical activity has a significant effect on physical fitness but physical activity has no significant effect on nutrional status to Surabaya vocational high school students.
\end{abstract}

Keywords: physical activity; physical fitness; nutrional status

\section{Introduction}

Sports and Health Physical Education is an education that can be carried out by doing physical sports activities, which aim to maintain and improve physical fitness, in which there are various aspects which include: speed, agility, strength and endurance. Physical Education is an important element in the growth and development of each individual human being. Physical education is useful for developing the skills, knowledge, values and attitudes needed to build and enjoy an active and healthy lifestyle, as well as building student confidence and competence in facing challenges both as individuals and as groups or teams through various learning activities- World Health Organization, 2002. p. 329. (Yusroni, 2019)

Improving the quality of a nation actually rests on improving the quality of its human resources, , and only one of them can be achieved through an emphasis on the importance of education (Muhardi, 2004, p. 478), then if education does not go well and the goals of education are not achieved, it will certainly have an impact on the quality of the nation itself. The constitution of the Republic of Indonesia in 1945 also discusses education that one of the goals of the State is to educate the life of the nation and then it is strengthened in article 31 paragraph 1 which states that every citizen has the right to receive teaching.

Seeing the importance of education, this research focuses on making an innovative learning specifically on physical education. Why physical education? Physical fitness is one of the main goals of physical education in Indonesia, according to the regulations of the minister of education and culture of Indonesia number.21 of 2006. However, the purpose of physical education seems to have not produced results when viewed from the last national scale survey in 2004-2006 in Indonesia by Mutohir \& Maksum (2007, p. 110) that the level of fitness of the Indonesian people in the years 2004-2006 has been declining year by year as evidenced by the scale of the fitness level 0,54 (middle category) in 2004, 0,352 (low category) in 2005, 0,335 (low category) in 2006. 
Table 1. Source: Mutohir \& Maksum (2007)

\begin{tabular}{cc}
\hline Number & Category \\
\hline $0,800-1$ & High Category \\
$0,500-0,799$ & Intermediate Category \\
$0-0,499$ & Low Category \\
\hline
\end{tabular}

Physical education should produce students able to be fit and healthy, but it is this inversely proportional fact that encourages researchers to make an innovation in physical activity in physical education learning that can make improvements to student fitness and more or less can help physical education teachers in achieving the goals of physical education.

Low fitness rates are also a factor in the high cases of obesity in Indonesia. In 2013 adult male obesity in Indonesia was 19.7\% higher than in 2007, and adult female obesity was $32.9 \%$ up 18.1\% from 2007 (Ministry of Health of the Republic of Indonesia, 2014, p. 122). These two survey results underlie this research in order to have a better influence on these two problems through physical education.

In this study researchers empowered homework in physical education to assign students to do physical activities at home 3 times a week for 2 months, with the hope that there will be an increase in fitness and good nutritional status that will be measured by BMI (Body Mass Index). Because physical inactivity is also a global health problem that has been identified as 10 main factors that initiate morbidity and mortality which has caused 3.2 million deaths each year (WHO, 2014, p. 33). Because of the importance of physical activity on the health and survival of humanity, the writing of this research is expected to have a healthier life impact in the future with the need for physical activity.

\section{Research Methods}

\subsection{Research Design}

The type of design used in this study is quasi experimental with non randomized control group pretest-posttest design method, and this study focuses on the problems that have been formulated, namely to analyze whether there is an effect of physical activity on physical fitness and nutritional status.

Table 2. Non- Randomized Control Group Pretest- Posttest Design

\begin{tabular}{ccc}
\hline$T_{1}$ & $\times$ & $T_{2}$ \\
$T_{1}$ & - & $T_{2}$ \\
\hline
\end{tabular}

Explanation:

$T_{1} \quad$ : Postest

$T_{2} \quad$ : Pretest

$\times \quad$ : Treatment

\subsection{Sampling Technique}

Determination of the sample in this study will use simple random sampling. According to Maksum (2012, p. 55) Simple random sampling is a sampling technique that provides equal opportunities for members of the population to become sample members. Fraenkel \& Wallen in Maksum (212, p. 62) recommend that a minimum sample of experimental studies be 30 
subjects divided into a control group and an experimental group. This study took a number of samples based on an explanation from Fraenkel \& Wallen, which is a sample of 30 students who will be divided into experimental and control groups, which are 15 samples in each group with different schools each group.

\subsection{Research Instruments}

Without knowing the right data collection techniques, the researcher will not get the data in accordance with established data standards (Sugiyono, 2013, p. 308). The instrument in this study used the Multi Stage Fitness Test to measure physical fitness, Leger \& Lambert (1982, p. 2) the objective of the Multi-Stage Fitness Test (MSFT) developed by Leger and Lambert is to monitor the development of maximum oxygen uptake . Meanwhile, to determine the nutritional status of the sample using Body Mass Indes measurements, WHO (2019) Body Mass Index (BMI) assessment can be determined by using a formula weight (kg)/ (m).

\subsection{Forms of Treatment}

The form of treatment that will be given to the sample is physical activity 3 times a week for 2 months with an intensity starting at $60 \%$ and continues to be increased every week which is controlled using the cardiograph application on Android. This form of treatment refers to Nurhasan, Priambodo, \& Roepajadi (2005, p. 24) who say that the frequency of effective exercise 3-5 times a week for 8- 15 weeks can already describe an increase in physical fitness.

This exercise program also refers to several journals, (Gim, \& Choi, 2016, p. 1359) "Gim, \& Choi, 2016, p. 1359) "The purpose of this study is to examine the effects of weekly exercise for each individual on the body's metabolic rate and $\mathrm{VO}_{2 \max }$. The results of this study are effective weekly exercises for $\mathrm{VO}_{2 \max }$, body metabolism and all are indicators of physical ability and physical fitness. More details will be shown in table 3 .

Table 3. Exercise Program

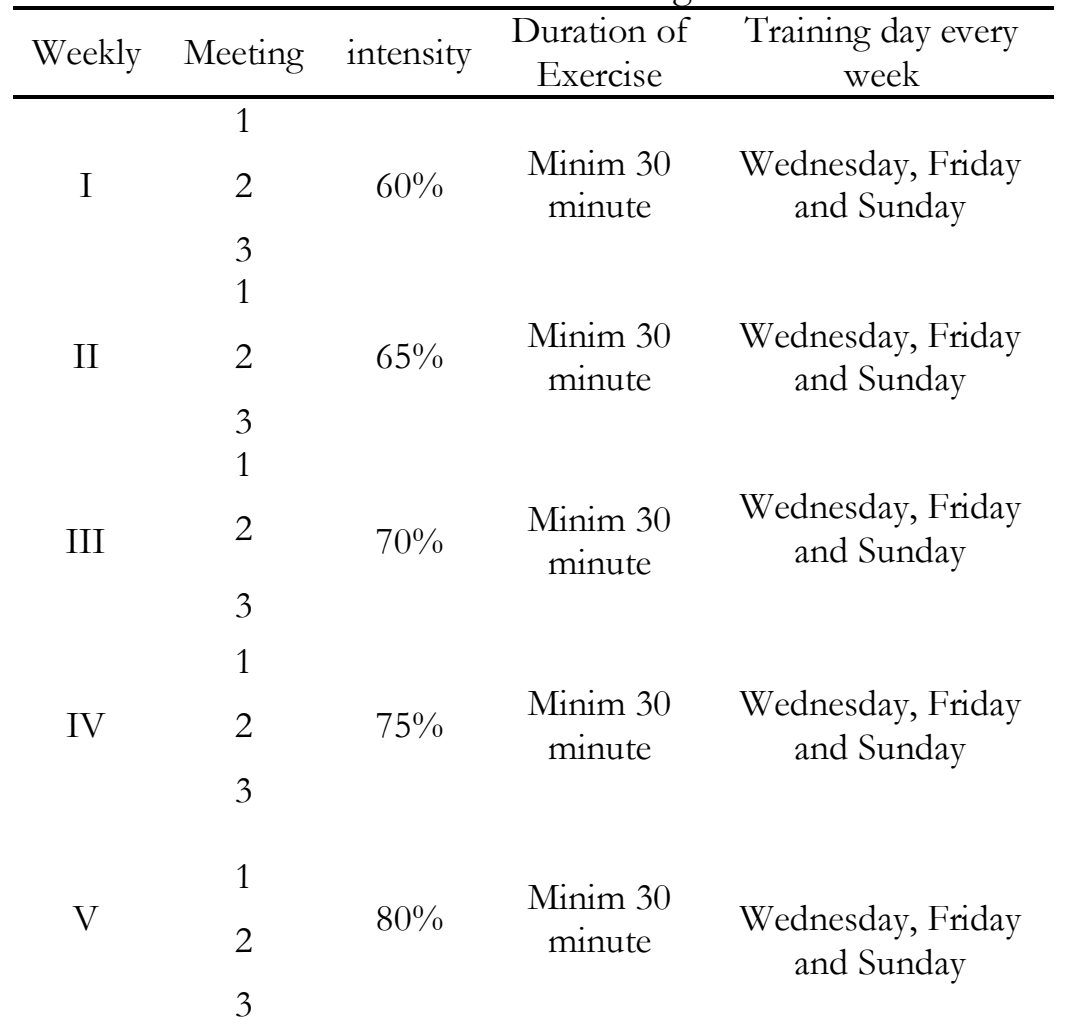




\begin{tabular}{ccccc}
\hline Weekly & Meeting & intensity & $\begin{array}{c}\text { Duration of } \\
\text { Exercise }\end{array}$ & $\begin{array}{c}\text { Training day every } \\
\text { week }\end{array}$ \\
\hline VI & 1 & & Minim 30 & $\begin{array}{c}\text { Wednesday, Friday } \\
\text { and Sunday }\end{array}$ \\
& 2 & $85 \%$ & minute & \\
& 3 & & Minim 30 & Wednesday, Friday \\
& 1 & & minute & and Sunday \\
VII & 2 & $85 \%$ & Minim 30 & Wednesday, Friday \\
& 3 & & minute & and Sunday \\
VIII & 1 & & $90 \%$ & \\
\hline
\end{tabular}

\section{Result and Discussion}

This study looks at the extent to which the effectiveness of providing physical activity treatment to fitness and nutritional status of class X vocational students in Surabaya. All of the following data will be analyzed using descriptive statistics with the stages of the statistical analysis process using SPSS version 22. Before testing the hypothesis first, testing is called the prerequisite test analysis, namely by conducting a normality test and homogeneity test data with a significant level of data of $0,05 \%$. After that the hypothesis testing using the t-test (paired test), and the test of influence using one-way ANOVA with a significance level of $0.05 \%$.

\subsection{Pre and Post Data Two Bound Variables from the Experiment and Control Group.}

The following are pre and post data obtained from MFT and BMI measurements in the two control and experimental groups.

Table 4. Pre and Post data in the control and experimental group with two dependent variables

\begin{tabular}{cccccc}
\hline Group & Mean & Variansi & Std. Dev & Min & Max \\
\hline Exp vo2max pre & 43,18 & 61,07 & 7,81 & 37,76 & 63,98 \\
Exp vo2max pos & 44,71 & 62,13 & 7,88 & 38,14 & 64,74 \\
Exp BMI pre & 21,10 & 1,79 & 1,34 & 18,75 & 23,78 \\
Exp BMI pos & 21,25 & 1,68 & 1,30 & 18,75 & 23,36 \\
Kontrol vo2max pre & 43,66 & 37,25 & 6,10 & 34,72 & 55,62 \\
control vo2max pos & 44,27 & 37,62 & 6,13 & 35,10 & 56,38 \\
control BMI pre & 21,10 & 2,16 & 1,47 & 19,00 & 23,78 \\
control BMI pos & 21,38 & 1,47 & 1,21 & 19,56 & 23,78 \\
BMI & 21,25 & 1,68 & 1,30 & 18,75 & 23,36 \\
Vo2Max & 43,71 & 62,13 & 7,88 & 38,14 & 64,74 \\
\hline
\end{tabular}

The table 4. describes the data used to determine whether there is an effect and whether there is a different effect that is given by the type of exercise. Pre-test and post-test data are used to determine the different effects of the type of exercise. If described according to differences in the pre-test and post-test scores, each treatment gives different research results. The difference between pre-test and post-test on VO2Max can be seen in Figure 1. While the difference between pre-test and post-test on BMI can be seen in Figure2. 


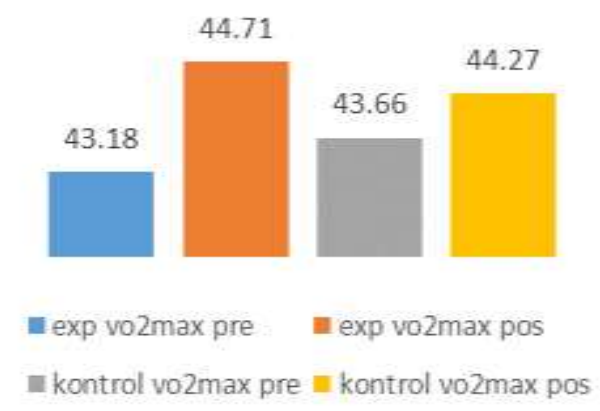

Figure 1. Changes in pre and post data on VO2Max

From the physical fitness test chart above, the experimental group scored 43.18 in the pre-test and 44.71 in the post-test, while in the control group it got a score of 43.66 in the pretest and 44.27 in the post-test.

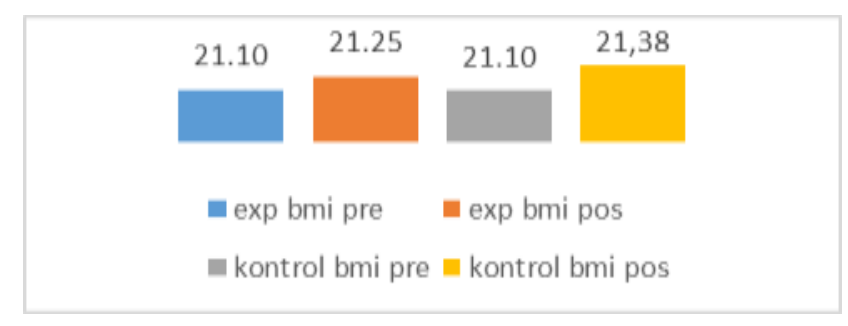

Figure 2. Changes in pre and post data on BMI

From the BMI score graph above, the experimental group got a score of 21.10 in the pre-test and 21.25 in the post-test, whereas in the control group it got a score of 21.10 in the pre-test and 21.38 in the post-test.

\subsection{Distribution Normality Test}

Distribution normality test is done as a prerequisite before testing the hypothesis. If the test requirements are met, then parametric testing is done using the $t$ test. However, if the requirements are not met, then use a non-parametric test. The results of the distribution normality test are shown in Table 3.2 as follows.

Table 5. Distribution Normality

\begin{tabular}{lcccc}
\hline \multicolumn{1}{c}{ Groups } & Statistic & df & Sig. & Information \\
\hline exp_vo2max_pre & 0,952 & 15 & 0,221 & Normal \\
exp_vo2max_pos & 0,914 & 15 & 0,201 & Normal \\
exp_bmi_pre & 0,954 & 15 & 0,594 & Normal \\
exp_bmi_pos & 0,966 & 15 & 0,790 & Normal \\
control_vo2max_pre & 0,916 & 15 & 0,170 & Normal \\
control_vo2max_pos & 0,917 & 15 & 0,176 & Normal \\
control_bmi_pre & 0,939 & 15 & 0,376 & Normal \\
control_bmi_pos & 0,922 & 15 & 0,207 & Normal \\
Vo2Max & 0,966 & 15 & 0,790 & Normal \\
BMI & 0,914 & 15 & 0,201 & Normal \\
\hline
\end{tabular}

Based on Table $5 \mathrm{t}$ is known that all groups show ( $\mathrm{P}>0.05)$ which means that Ho is accepted, thus all groups have a normal distribution. Before testing the hypothesis, a second prerequisite is tested, namely the homogeneity of variance. This test is done because the third 
hypothesis in this study states that there are differences in the effect given by each treatment. This prerequisite test is used to determine whether testing using anava can be done or not.

\section{a. Homogeneity Variance Test}

The prerequisite test conducted next is the testing of variance homogeneity. This test is carried out to determine whether the two groups tested have homogeneous variants. Testing the homogeneity of variance using levene test with an error level of $5 \%$. If the Sig value $>0.05$, it is concluded that the data have homogeneous variants. The results of testing using SPSS 22 are shown in Table 6

Table 6. Homogeneity of Variance

\begin{tabular}{lccccc}
\hline & Levene Statistic & df1 & df2 & Sig. & Information \\
\hline Vo2Max & 0,343 & 1 & 28 & 0,563 & Homogen \\
BMI & 0,153 & 1 & 28 & 0,698 & Homogen \\
\hline
\end{tabular}

The results of calculations using SPSS obtained a significance score of 0.563 for VO2Max and 0.698 for BMI. Based on these results it is concluded that all groups have homogeneous variants. Both prerequisite tests have been fulfilled, then hypothesis testing can use parametric testing.

\section{b. Test Influence of Treatment}

Test the effect of treatment using $t$ test analysis techniques namely paired sample $t$ test. This test will calculate the mean difference of two groups in pairs. The error level used is $5 \%$. The conclusion is based on the Sig value in the calculation using SPSS. The test results are shown in Table 7 as follows.

Table 7. Results of Analysis of the Effects of Experimental Group Treatment

\begin{tabular}{lcccccc}
\hline & Mean & Std. Deviation & $\mathrm{t}$ & $\mathrm{df}$ & Sig. & Explanation \\
\hline VO2max & $-0,53$ & 0,34 & $-5,95$ & 14 & 0,00 & $\begin{array}{c}\text { There is } \\
\text { influence } \\
\text { BMI }\end{array}$ \\
\hline
\end{tabular}

Tabel 8. Results of Analysis of Effects of Control Group Treatment

\begin{tabular}{lcccccc}
\hline & Mean & Std. Deviation & $\mathrm{t}$ & $\mathrm{df}$ & Sig & Explanation \\
\hline VO2max & $-0,60$ & 0,40 & $-5,87$ & 14 & 0,20 & $\begin{array}{c}\text { There is no } \\
\text { influence }\end{array}$ \\
BMI & $-0,28$ & 0,64 & $-1,69$ & 14 & 0,11 & $\begin{array}{c}\text { There is no } \\
\text { influence }\end{array}$ \\
\hline
\end{tabular}

The results of calculations using SPSS obtained a significance score of 0.00 for VO2Max and 0.60 for BMI, while the control group obtained a significance score of 0.20 for VO2Max and 0.11 for BMI. Based on these results it is concluded that physical activity has a significant effect on VO2Max and physical activity does not have a significant effect against $\mathrm{BMI}$ in the control group. Whereas the two dependent variables in the control group gave insignificant results. 


\section{b. Different Tests for Treatment Effect}

The next test is testing to find out whether there are differences in the effect given by each treatment. Testing using one way anava with the help of the SPSS program. The error level used is $5 \%$. The test results are shown in Table 9.

Table 9. Results of Analysis of Differences in Effect of Each Treatment

\begin{tabular}{llccc}
\hline & & df & F & Sig. \\
\hline Vo2Max & Between & 1 & 0,72 & 0,01 \\
& Groups & & & \\
& Within Groups & 28 & & \\
\cline { 2 - 4 } BMI & Total & 29 & & \\
\cline { 2 - 4 } & Between & 1 & 0,47 & 0,00 \\
& Groups & & & \\
& Within Groups & 28 & & \\
& Total & 29 & & \\
\hline
\end{tabular}

Table 9 shows the results of the calculation of the different treatment effects using the SPSS program. Based on the calculation results obtained significance values of 0.011 on VO2Max and 0.00 on BMI. Both of these values are smaller than 0.05. It can be concluded that there is a significant difference in the effect given by each training program, but a greater impact is seen on the VO2Max dependent variable than the BMI dependent variable. This study did not use post hoc analysis because it only used two treatment groups.

\section{Conclusion}

\subsection{Dampak Aktifitas Fisik terhadap Kebugaran Jasmani}

Based on the results of data analysis using SPSS, physical activity has a significant effect on VO2Max with a score of 0.00 . This is in accordance with what was stated by Skogstad et al (2016, p. 1) several activities 2-3 times a week for 8 weeks showed an association with physical fitness to maintain blood pressure for better and more favorable lipid status compared with physical activity someone who rarely does physical activity. Eather, Morgan, \& Lubans, 2013. After exposure to the SPSS calculation results and quotes from similar studies above, it can be concluded that physical activity with sufficient intensity and frequency can have a significant effect on one's physical fitness.

\subsection{Impact of Physical Activity on Nutrition Status}

Nutritional status is the condition of a person's body condition from food and its use by the body that can be measured with various dimensions, one of which is the measurement of BMI as in this study. Many factors also influence it, one of which is physical activity that will be tested in this study. The relation of physical activity to nutritional status gets results Sig. based on calculations using SPSS of 0.60 for BMI.

Based on these results it can be concluded that the physical activity program in this study did not have a significant effect. In the journal by Bogna et al (2016, p. 261) "students with high levels of physical activity and little carbohydrate consumption will have a better effect on diet programs compared with low levels of physical activity". Looking at the journal by Boga and friends, to get the most out of the diet program you must also control the intake of carbohydrates in the sample. So the lack of strict control on carbohydrate intake in this study which could have been one of the factors causing the experiments in this study did not affect the nutritional status of the sample. 


\section{References}

Bogna, G. G., Andrzej, J., Natalia, K., Juliusz, P., Agnieska. S. J., \& Elzbieta, K. (2016). Physical activity, nutritional status, and dietary habits of students of a medical university. Sport Sci Health. Advance online publication. Doi: 10.1007/s11332-0160285-x

Gim, M. N., \& Choi, J. H. (2016). The effects of weekly exercise time on and resting metabolic rate in normal adults. The journal of physical therapy science. 28 (4), 1359. Downlaoded from: https://www.ncbi.nlm.nih.gov/pmc/articles/PMC4868243/pdf/jpts-28-1359.pdf.

Leger, L. A., \& Lambert, J. (1982). A maximal multistage $20-\mathrm{m}$ shuttle run test to predict . European Journal of Applied Physiology. 49 (1), 1-5. Downlaoded from: https://www.esearchgate.net/_publication/15997021_A_maximal_multistage_20m_shuttle_run_test_to_predict_VO2_max/download.

Maksum Ali, (2012). Metodologi Penelitian. Surabaya: Unesa University Press.

Ministry of Health of the Republic of Indonesia, (2014). Profil Kesehatan Indonesia Tahun 2013. Jakarta: Kementerian Kesehatan Republik Indonesia. Downlaoded from: http://www.depkes. go.id/ resources/download/pusdatin/profil-kesehatanindonesia/profil-kesehatan-indonesia-2014.pdf

Mutohir, T.C, dan Maksum, A. (2007). Sport Development Index: Konsep Metodologi dan Aplikasi. Jakarta: PT Indeks.

Nurhasan, Priambodo, A., Roepajadi, J., Indriarsa, N., Ivano, R. A., Christina, S. Y. H., Tjateri, G. A., Juniarto, P., Djawa, B., Wibowo, S. (2005). Petunjuk praktis pendidikan jasmani. Surabaya: Unesa University Press.

Skogstad, M., Lunde, L. K., Skare, O., Mamen, A., Alfonso, J. H., Ovstebo, R., \& Ulvestad, B. (2016). Physical activity initiated by employer and its health effects; an eight week follow-up study. BMC public health. Advance online publication. Doi: 10.1186/s12889-016-3035-8.

Sugiyono. (2013). Metode Penelitian Pendidikan : Pendekatan Kuantitatif, Kualitatif, dan R \& D. Bandung : Alfabeta.

WHO. (1995, 2000, 2004). BMI Clasification. Diunduh dari website: http://apps. who.int/ bmi/ index.jsp?intro Page=intro_3.html.

Yusroi, M. (2019). The Effect of Individual and Group Jump Rope Games on Physical Fittnes and Motivation. Budapest International Research and Critics in Linguistics and Education (BirLE) Journal. P. 648-652. 